\title{
NOTION OF STRATEGIC NATIONAL SECURITY MANAGEMENT
}

\author{
Prof. Remigiusz WIŚNIEWSKI, PhD \\ Pawel Wlodkowic University College in Płock
}

\begin{abstract}
An analytical description of the community, national strategic management of national security as the foundation for shaping the security of the state with the display of combined actions of diplomacy, administration and generally understood management of knowledge. An attempt to create a package and objectives in the context of a comprehensive strategy as a concept of a concrete action of the state to promote wise and civic science-common in the cause and effect relationship of the strategy as a security instrument.
\end{abstract}

Keywords: national security, state security, strategy, management, planning

\section{Notion of strategic national security management}

The very issue of global state security shaping is usually approached from very different perspectives with the concurrent use of the adequate knowledge verification and scientific cognition criteria. It is the ultimate outcome of very different opinions, ways of explanation forming the diverse paradigms of acting through the subjects, moreover their qualities are determined by the distinct attributes, which often entails a certain cognitive dissonance. The immediate effect of this dissonance is, in most cases, the narrowing or broadening of the general topic closely related to adequate national security shaping. This knowledge domain is also crucial as far as the cognitive aspect is concerned because it comprises all 
the possible types of undertaken activities, which determines whether a country is able to guarantee its own safety in the contemporary world. Furthermore, this domain describes in detail the position and the general significance of the subject in social relationships. It is worth emphasising another important context, although one might say that the subject of national security as such has already been exhausted. However, the reality clearly indicates the new and yet undiscovered elements, which should have been, yet have not been taken into consideration by the practitioners and decision makers as well as by the experts and scientists (Kapłan 2008, p. 73).

Considerations on the security of Poland should, after all, be a continuous process, evaluating the proposals for changes and improvements that are completed each time. Therefore, many questions arise not only about the main elements of strategic management of national security, but also, and perhaps firstly and primarily, about its goals, content, processes, methods, means, institutions, etc.

Determining the dynamics of its development and the possibility of making necessary improvements is, thus, a complex activity. Therefore, the main objective of the considerations may be considered as a comprehensive, multi-layered analysis of the strategic management system, emphasising its utilitarian character. Formulating problem conclusions which encourage further research in the matter described and gradually make it more specific and precise.

This praxeological interpretation of the thorough understanding of security as a whole refers to the way the approved security theory is constructed and used as a source of knowledge in the adequate creation of the future, or rather the future states of affairs which are based on the current academic achievements in organisation and management, political science, international relationships, art of war etc. In comparison, the State security is a consequence of the ideas included in the numerous theories determining the activities undertaken with clear purpose and precision following the previously cognitively verified decisions. It is also the final result of the very relationship between thinking and acting in a relatively unique domain of security providing and its secondary construction, the active endeavour to achieve future desired states of affairs or the potential necessity to face those that are deemed completely undesired. This includes all the vast specifics of state activities: the internal, external and global. The said activities exist in direct relation to the many conditions that an efficient state should fulfil. 
Hence, the whole strategic national security management formation includes the critical idea in which it is the state security that forms the ultimate consequence of undertaken, dismissed or abandoned activities in the dynamic circumstances of social reality (Gryz 2013, p. 86).

Focusing on the possible ways of acting and ensuring security of various social subjects goes back to the dawn of each civilisation that appeared, altered and vanished in time. For its primal form is expressed by the relationship between power and politics, sacrum and profanum, their material and intellectual artefacts, traces of which can be most often found in time and space. Therefore, it is impossible to present the entire spectrum of the issue. It is a mere approximation, a fraction of what in its entirety forms knowledge about this vast domain. For it includes the organisation and legitimisation of political power, managing social groups, concentration on ultimate goals achievement, shaping all the tangible and intangible instruments of advantage enabling one to ensure the existence and development in fullness according to one's own depiction of oneself and of all the surrounding world (Gryz 2013, p. 87).

The very notion of strategic security management, or rather the contemporary interpretation of what we directly find in the past centuries and millennia, appeared in the source literature as early as at the turn of the $20^{\text {th }}$ and $21^{\text {st }}$ centuries. This notion was directly related to the designed strategic management of state policy as the ultimate consequence of attributing to the new formula all the activities including: diplomacy, resources and knowledge management. This task was carried out at the meeting point between the internal and external state policy, originally in Denmark, in the Copenhagen School of International Affairs and then, by analogy, in other countries of Western Europe (Christensen and Petersen 2005, p. 58).

The specific qualities of management formula at the time mostly involved the civil domain including the reaction in the face of internal (within the territory of a given state) and international crises. Against this background, all the political and military domains served as a catalyst of sorts to the ways of thinking and acting that was in turn connected with the changes occurring on a daily basis in the milieu of the international security at the turn of the $20^{\text {th }}$ and the $21^{\text {st }}$ centuries (Kugler 2006, pp. 15-16). 
The signum temporis and the indispensable pressing need after the 9/11 attacks in the United States became the task of the traditional combining of the two domains into one synergic whole, extended by the previously unheard of, important elements such as cyberspace. In the whole political and military domain, any practical concrete decisions made in 1999 and entirely concerning the reorganisation of the North Atlantic Treaty and the European Union became the expressions of the logical thinking and efficient strategic management guiding the activities of multiple countries. Those decisions were almost immediately related to the proper adaptation of the said organisations to the circumstances of international environment (Gryz 2013, p. 88).

The practical expression of this fact was all the concepts concerning the numerous changes in the form of Defence Capabilities Initiative, or DCI in case of the NATO Headline Goal, from 2004 called Headline Goal 2010, in the case of the European Union. Both initiatives have been additionally fortified by the numerous, detailed packages of active operations, such as specifying in detail the nature of cooperation between these two subjects (ed. Gryz 2008, pp. 129-144).

The initiatives started to entail the practical operations of states mainly in the political and military domain. The best example of which might be the subsequent meetings between the heads of states and heads of NATO and, the EU in the first half of the decade.

The strategic management of all security mainly concerning knowledge, abilities, goals, management and use of possessed resources, meeting the identifiable challenges became the basis for the highly specialised commanding cells that took over such duties. In the case of international organisations this activity took place with the active participation of NATO's Allied Command Transformation, or ACT, formed on June 19, 2003.

In the context presented above, all the strategic security movement relating directly to the political and military domain ultimately took the form of:

- International organisation operations (mainly the NATO and the EU)

- Executing multiple operations on the international agenda by the states

- Various organisations and states' adaptation to the current requirements and forecast shifts in the international security environment. 
- Various state structures' adaptation to the general requirements of contemporary security

- Implementing education concerning the very important areas specified above (ed. Gryz 2008, p. 145).

The areas enumerated above are fundamental and can be further isolated based on the detailed analysis of state and other international organisations' activities (the $\mathrm{NATO}$ and the EU). Even though the strategic management of the security domain is a typically scientific issue, it is still a relatively new issue and unknown in Poland. Initially, it has been treated as the fundamental part of general management and its interpretation can be found in the numerous works created in the Strategy Department of the former Strategy and Defence Faculty at the National Defence Academy. As a result of the works created there, the specific area of the detailed research within the domain of the contemporary military science as well as within the scope of the prominent research issues, forming the central subject of cognitive interest was specified. It should be explicitly emphasised that due to its own specifics, the strategic security management has never been described in its entirety. However, the utility of the received results and the ease with which they can be further properly verified entailed the treatment of the strategic security management as a specific area of knowledge with the specifically determined interpretation. (Gryz 2013, p. 89).

In the past, the basis for such knowledge concerning the strategic security management was the leading research premises transposed on Polish soil mainly from American, French, British, German, Soviet and Russian academic achievements. Such is the case at present. In the so-called synergic way, they created the native, fundamental interpretation of strategic security management. The borrowings from any given economic, organisation and management sciences as well as the praxeological approach and general political science perspective being its chief qualities. This individual interdisciplinary approach has been neither fully researched nor specified. It is also worth noticing that in spite of such a state of affairs, the general scope of research is successively expanded and has started to include other domains of knowledge too (Lisiecki 2011, p. 54).

Therefore, the whole strategic security management is the utilitarian form of the best possible cognition containing in itself the basic interpretation, which makes it possible to understand and specifically determine the social reality, the 
various processes it undergoes, as well as the related phenomena and random activities. As such, it forms a very important instrument of scientific cognition and the permanent tool that can be used in the further creation of reality, future desired states of affairs. For it creates the fundamental basis of knowledge mainly in the scope of the undertaken and projected activities. The strategic security management by combining the utilitarianism of scientific cognition with praxeology creates the distinct advantage of the social subjects over others very similar to them. The indispensable knowledge it includes refers to the past - its behaviour and ultimate results, the present - specifying the exact activities and its top-down assumed outcomes and the future - projecting the activities of one's own as well as of other social subjects (Leszczyński, Gumieniak, Owczarek and Ochocki 2013, p. 34).

By all means, one can attribute numerous functions to strategic security management. First of all, those relating directly to abstracting, that is creating, setting apart, identifying certain important features, qualities identical with complex processes of thinking about security, and against such background creating various notions: forming theorem, ultimate judgements and notions; making key decisions (in a situation of choosing from at least two alternatives, choosing the optimal one which is not equivalent to active operation undertaking); organising and detailed planning; problem solving. Those functions clearly indicate the scope of interest that constitutes thinking about security (Lisiecki 2011, p. 55)

The focus of social subject activity on ensuring the best possible existence and development absolutely demands proper identification of the desired and actual state of affairs in all its structures (in the case of a state, it refers to its governing bodies) (Nęcka, Orzechowski, Szymura 2009, p. 549). In the case of organised social subjects, it refers to their mission and vision. The assignation of the subject's activities to the successful realisation of its mission and vision allows one to expose its very nature, the very core of the strategic security management assigned to the present, yet exceeding it, reaching out into the future. The social subject mission, however, takes the form of the multilayered, multidirectional activities focusing mainly on ensuring its existence and further development. The nature of these very ventures is to combine in a compatible way all the resources and their implementation within the scope of the achieved policy and strategy (Koziej 2001, p. 20). 
The aims of a state are always achieved both in the conceptual way, that remain entirely compliant with the strategy as the concrete action concept, and as a method or many methods of action. Secondly, the mission of a state is closely related with its vision and goals formed in this very area. The mutual relationship between these concepts deserves to be clearly and strongly underlined. For it determines all the current subject policy, the realisation of the previously accepted and designed strategy and it precisely specifies which of the undertaken activities shall be continued in the future and in what form. Ensuring the long-term survival of a state also requires from the governing bodies the formation of its vision, mission and strategic goals of the state. Thus, it involves all the general, longterm notions about the future state and position of a given country. As such, this vision involves individual, very important features making the strategic security management possible (Leszczyński et al. 2013, p. 38).

The first of them is the orientation of activities. This vision also creates a peculiar point of reference, which enables the compliance verification of all the current activities with the long-term operations whose aim is mainly its efficient implementation as well as with their fundamental values. The second one is the authentication of the activities. This vision is the peculiar official declaration of intent; consequently, it is a very important communication tool making the use of social engineering possible. The third one is the activities' integration. In society as a whole, this vision evolves into a shared, completely new value, around which all the emotions and effort of both individual citizens and all of society are focused. The fourth one is inspiration to the top-down type operations. This vision becomes a point of reference for all the current, short or middle- term state activities. It can by all means form a peculiar tool for the proper verification of the progress made, changes directly aimed at considerably better, more efficient implementation of activities and intentions stemming directly from the vision realisation. The fifth one is strengthening the previously undertaken activities. Thus, the vision creates the conceptual, target model of the "realistic reality" involved in the promise of its implementation. This fact forms in society as a whole, that is, among all the citizens, a sense of certain durability of the system they found themselves in. Therefore, by implementing the traditional and proper interpretation of relationships between the mission of the subject and its vision, it can be clearly indicated that together they lead to: 
- The specification of the subject's strategy deployment, that is the policy realised mainly in the form of the previously carried out operations of government officials

- Ensuring the key financial, personal and other recourses for the sake of the better implementation of a given subject's security strategy

- The formation and drawing up of the competition, conflict and active struggle strategies in the very subject's strategic environment.

- The management of efficient strategy implementation and its constant supervision including, among other things, managing risk, change and development, managing with vision and managing in various emergency or crisis circumstances.

The interpretation presented above clearly only illustrates the outline of various relationships between a given subject's mission and vision. Each time, their nature will depend on the type of social subject and on its undertaken or dismissed activities. For the nature of state activity differs from one of the societies in the non-organised states and from activities of such subjects as huge international corporations and is totally different in the case of numerous social groups (e.g. criminal or terrorist). The essence of the undertaken activities, common for all the previously mentioned, is the correlation of all the current activities with the future and intended ones. By all means, this forms the heart of the matter and the one, common interpretation in which it is only the ultimate outcome that counts (Koziej 2001, p. 21).

If, as the main point of reference to all further discussion, the acknowledged statement that a given social subject's policy and the whole security strategy is the final outcome of its active aspirations to shape the reality, then the basic issue is certainly the characteristics of the way all its activities aimed at that outcome are organised. Among them, it is particularly important to indicate the following (Leszczyński et al. 2013, p. 39):

- The division of the tasks and competence within the organisation that ultimately stem from the already existing final solutions of a functional nature, specified by the current norms;

- The rules of cooperation between all organisation members during the time when the numerous problems including the competence areas of some of them are being solved. 
- The internal structure fully adequate to the top-down accomplished tasks

- The rules of resolving the disputes that stem within the organisation.

To sum up, the complex activities of all the governmental bodies ruling the social organisations directly oriented on the ultimate outcome constitute the main foundation for providing the holistic construction of the effective security system. They are also definitely the hardest to define as an element of this system. In the area where quite numerous contradictions may occur, it can result in its being the weakest link and according to the drawn theory of systems, it is the weakest link that proves how durable the whole structure is.

\section{Strategic national security management circumstances}

Strategic security management as a whole is accomplished in the circumstances of the active close vicinity impact on the subject of security and vice versa. It is also connected with the acquisition and use of all the potential to meet all the challenges, threats, chances and risks resulting from its nature (Lisiecki 2011, p. 56). Namely:

- Interaction with other subjects

- Security environment

- Internal (intersystem) and external conditions of the subject's activity realisation.

Therefore, strategic management of all security is the organised concept of management including a detailed description of the interconnected elements included here (Gryz 2013, p. 101). They include:

1) a constant and active aim to completely meet the turbulence of the social subject's vicinity and depending on its character (e.g. state, international community), also the internal one. This conceived imperative forms the foundations of all the actively undertaken activities and directly entails very important, typically cognitive implications. For it creates a certain paradigm of knowledge and ignorance mainly concerning the same subject, its close vicinity, other subjects as well as the interaction between them in time and space. The paradigm involves the required knowledge about the surrounding world, social reality 
and its functioning. It comprises at that many various prevailing theories, laws, notions and, last but not least, concepts of the whole world around us;

2) a constant and active aim to build and maintain a clear advantage over other social subjects, forming mere potential competitors in their access to goods and their just division. In the case of this criteria identification in the scope of politics and international relations, the key concept that remains is the notion of the very power of the social subject. The exemplification of this phenomenon is best illustrated in his equation by Ray Cline (Cline 1975, p. 11). It presents all the components of the power of a social subject as:

$$
P=(C+E+M) \times(S+W)
$$

In this approach, $\mathrm{P}$ means Power, $\mathrm{C}$ is Critical Mass (meaning population and territory), E means Economic Potential, M means Military Potential, S means Strategy and W the Will to implement this strategy (Gryz 2013, p. 102).

All the components mentioned above are analysed in a slightly wider strategic perspective as the differentiation of power. Among them one might find: the size of territory, the characteristics of its borders, size of population, the lack or existence of natural resources, economic and technological development, financial strength, natural uniformity, degree of social integration, devised political stability and national morale. The elements that compliment this picture are the numerous social structures, institutions of external (international) and internal nature.

3) the constant acquisition and proper use of their own resources in a totally deliberate way as well as in a way provided by other social subjects in order to carry out and strengthen their own activities. Among such resources are:

- Human resources, i.e. various abilities, knowledge, other abilities and numerous predispositions of the people forming a social organisation.

- Financial resources, i.e. the capital which the organisation uses to finance the activities that are both current and long-term.

- Objective resources, i.e. among others, the resources, products, infrastructure and equipment of various type and use.

- Information resources, i.e. any type of data that is fully useful and even indispensable for the successful key decision making (Griffin 2004, p. 5).

The foundations for the creation of all the aforementioned resources are created by nature and are renewable (permanently able to provide useful products) and 
non-renewable, (those which might be used only once or for a short period of time due to the limited access to them) (Samurldon and Nordhaus 2004, p. 642);

4) searching for any interactions with other social subjects in order to gain a clear advantage over the others. Such types of undertaken activities never exclude the concurrent and durable constructing, maintaining the advantage over other social subjects, which are by all means potential competitors in gaining the access to goods, their proper division, those that found themselves in the allied relationships or others. In most cases, the aspiration to create a complete symbiosis of the two types of activities forms the foundation of the activity concept in the form of a drawn security strategy of a social subject. In the relationship, the big issue remains the exact specification of the relationship character. The example in this subject may be by all means the interpretation provided by Robert Kapłan. He stated that "In spite of what we might think or imagine, human behaviour is ruled by fear, personal interest and honour. All these aspects of human nature are fully responsible for war and instability and form the human condition. This condition leads in turn to serious political crises where pure instinct prevails over the law and politics gives way to anarchy. The successful method to overcome anarchy is not the negation of the existence of fear, personal interest or honour but their constant control in order to achieve the adequate moral results" (Kapłan 2008, p. 79);

5 ) an act of creating the numerous reasons for gaining an advantage over other social subjects by the proper shaping of the adequate conditions for carrying out the active policy and strategy of the social subjects associated in communities, states and organisations. Their individual nature indicates other institutional factors such as those which fully determine their ability to carry out a policy and implement a strategy. This very aspect of social subjects' activity straight out induces one to treat their activities in the numerous organised social structure systems in a systematic way. For every time those structures will be different, mainly depending on which subject and in what exactly social environment will accomplish its undertaken activities. As it was finally stated by Samuel Huntington, "the main political difference between countries refers not to their form but to the degree of government. The differences between a democracy and a dictatorship are smaller than the difference between the countries whose policy represents the consensus, community, law and order, good organisation, 
effectiveness and stability than between the two countries in whose policy such qualities are lacking "(Gryz 2013, p. 103).

A social subject that possesses the drawn operational strategy will always form an adequate security zone aimed mainly at the final achievement of the assumed goals. It should be underlined that each time it will be done in a way adequately different depending on the type of the social system that abides (Gryz 2013, p. 104). The example in this matter can be the activity of different types of society. The particularly interesting factor is the degree to which they are organised or to which they lack such organisation. For in the anarchy, a new order must occur in order to enable its transformation into further, new forms of organisation.

Depending on the current view of the social world, whether it is a functional one or a conflict, one difference shall be the determinants that form the fundamental basis of the strategic security management. Every time such activities are directly aimed at the benefits, then such benefits shall be interpreted in the subsequent categories of existence ensuring further development. In such a way, they will find their legal, ideological and doctrinal interpretation.

By the use of the social reality interpretation on the basis of numerous conflicts, the activities of subjects on the ground of a social relationship within the specified communities will be a very important decisive factor, adapted to the very nature of this official system. The cognitive tool and, at the same time, one to achieve the full understanding of reality is ideology. In its extreme form, as a main basis of human behaviour categorisation, its basic expression can be found in political extremism doctrine. Roman Tokarczyk, while defining the character of his study, indicates that all such doctrines are described in detail as: antidemocratic, dogmatic, fundamentalist, repressive, terrorist and other. Any attempts to exceed the onedimensional cognition of political extremism towards its multidimensionality, as such, are most often met with the fundamental difficulty to construct the adequate concept that may serve this purpose (ed. Olszewski, p. 13-14). As it is clearly underlined by Raymond Boudon, the essence is the very obligation imposed on individuals, and in consequence on entire groups by the working social structure (Boudon 2009, p. 155).

In case of international society, the situation looks different, although the logic is very similar. Robert Gilpin indicates that within the scope of international 
community, the whole international system is permanent as long as the state does not see any benefits from the potential change. However, if the state is expecting certain benefits that exceed the potential losses, it strives for immediate change. For example, by extending its current territory, increasing its economic power, gaining full control over the resources and other very similar elements that can be treated as the power of subject components. However, the state of balance is reached only when the losses and potential benefits of further expansion counteract each other.

Consequently the tendency to maintain the status quo is increased. The international system itself is balanced out better if the countries are able to maintain this permanent balance. If they are unable, then the system undergoes further processing (Lisiecki 2011, p. 73).

In the case of typically strategic security management social structures in the complex processes of institutionalisation serve the transposition of social roles and relationships in a specifically defined social hierarchy, making the independent, political decision making possible. According to the published interpretation of the organisation and management science, through those structures the so-called functional and institutional management take place (Wojtaszczyk and Jakubowski 2002, p. 126-133).

In the typically institutional approach, the strategic security management will always be the source of serious changes in a given community or a given system related directly to the expressly specified needs and will include the activity of a group of people as well as of the whole community constituted by them. Moreover, these will include any organised system of human activity that involves purposefully united groups of people that are fully prepared and equipped. According to the thoroughly presented interpretation, the strategic security management is a concept of organising human groups in order to always undertake clear purposeful activities within the specialised social institution framework. The consequence of such organisation - the culture of organisation expressed as strategic culture should be duly noted here. The latter de facto clearly specifies the organisation's ability to carry out activities, successfully accomplish them in time and space. The same refers to the synergy and flexibility in the context of the ever changing effective determinants as well as the capability of full adaptation. Strategic security management is a very important function of policy and strategy 
of an organised social subject, its thinking and acting fully based on the idea of security. As such, it expresses the active aspirations of social groups comprised in numerous social doctrines (Gryz 2013, p. 105). Among them are:

- Striving to gain full power and influence;

- Keeping power, exerting considerable influence and maintaining both;

- Projecting the future desired state of social reality in order to maintain central power and exert influence.

This approach makes it possible to exercise further division into:

- Social subjects

- The character of interaction between them

- The determinants of their activities

- The social factors in which they carry out their activities.

The approach presented above clearly indicates the typical systemic form of thinking and active operations of social subjects in the scope of the strategic security management. At least in reference to the presented interpretation.

\section{National security management organisation}

The condition of the highly efficient functioning of a state is the universality of all the activities by various bodies and institutions of public administration. To fulfil this important condition, one must absolutely strive to set the integrated strategic planning system always understood as the activities assigned to the successful accomplishment the ultimate aims resulting from the national security strategy. The forms of the overall realisation may in practice be expressed in the form of detailed plans and programmes, which, in relation to the drawn strategy, will constitute their main interpretation.

It is worth underlining that the universality of activities of a given state's various bodies and institutions of public administration should entail the fulfilling of the conditions of (Koziej 2001, p. 23):

- Completeness

- Responsibility

- Exclusiveness 
- Feasibility

- Acceptability

The multinational character of the undertaken activities determines the need of a common and detailed planning for all the state governmental bodies; however, such planning is also accomplished separately. The starting point and the reference point of the strategic planning is always the intended final condition. It is a highly desired security situation, not only a national one but also of an ally. The main goals derive from the desired condition and they are further disintegrated into the military and non-military. The categorisation of goals result in the immediate necessity to plan and accomplish the cooperation between various bodies of a state. Against such background, one is implied to indicate the necessity to ensure the operation of any public administration bodies in the scope of a nation as well as of the state structures, even in their supranational dimension. The conditions necessary to achieve the highly versatile coordination of state activities are (ed. Gryz 2008, p. 145):

- The synchronisation of the undertaken activities

- The cohesion of the efforts made

- The identification of challenges, threats, opportunities and the constantly accompanying risks

- Specifying the criteria and all decisive points

It is possible to indicate the main, central directions of the activities mainly in the scope of cooperation of the public administration bodies for the sake of complex strategic planning. They are (for a time of war, crisis and war) the following (Gryz 2013, p. 106):

- Forming the normative and typically organisational foundations for the administrative bodies activity

- Maintaining and permanent creation of civil and military readiness concerning any type of state activity

- Preparing the appropriate state service

- Supporting the active decision process

- Preparation and further education of public administration

- Ensuring the proper conditions for the accomplishment of activities and public administration functioning 
- Creating the conditions for the adequate protection and defence of the population as well as the respectful functioning of society

- Supporting the joint operations of allies and coalition partners

- Active international cooperation

- Implementing the detailed proceedings of international help

Those are not all the directions of the undertaken activities or even the most important. However, they allow one to indicate the main foundations of strategic planning.

The main issue determining the security system's efficiency is usually attributing to it a character of a fully integrated, coherent and organised whole. Therefore, the National Security Strategy is created. This is a prominent, ever evolving document in which the formulation of elaborate mechanisms of complex and yet long-term planning of security system development based entirely on clear goals and common needs for all its components, resulting from the holistic approach to global and national interests is predicted. Against such background, the most important basic question remains the highly effective integration of a security system concerning all its component forces.

Therefore, mostly in a top-down manner, the suitable modification of some proposed legal resolutions is predicted. Thus, it should lead to the adequate organisation of national security system construction, the precise specification of all the competences of its individual components, including the governing bodies and the substantial increase of the possibility of cooperation between all the individual departments (Koziej 2012, p. 11).

According to S.Koziej's approach in Poland, one can distinguish between two levels where the conceptualisation and the so-called concretisation of the activities mainly in the scope of national security may be observed. The first of these is conceptual and the second one related to planning.

On the first level, the holistic state security strategy is formed as well as its derivative defence strategy. It should be duly noted that the shape of the Republic of Poland's National Security Strategy is considerably influenced by NATO's Strategic Concept and the Security Strategy of European Union. However, with the reservation that the precisely described model on this level is not entirely shaped in the correct way. Two areas can be differentiated. The first of them is the 
strategic and operational planning. It includes the Political and strategic defence directive with the following derivatives (ed. Gryz 2008, p. 146):

- The plan of the Republic of Poland's Military Forces use and operations

- The plan of individual governmental bodies' functioning on all possible levels of state in each of the constitutionally defined states of operation (state of peace, crisis and war).

The second area is defence programming and budgeting. It involves the following (Gryz 2013, p. 106):

- Defence perpetration programmes designed for many years

- The Republic of Poland's Armed Forces development programmes designed for many years

- Governmental bodies' defence preparation programmes designed for many years. The bodies include all the state levels in each of the constitutionally defined states of operation (state of peace, crisis and war).

It should be clearly noted here that due to the existing solutions that are not yet precisely organised and properly normalised, the periodic verification of accomplished strategy and plans does not occur. Moreover (Karkoszka 2009, p. 19):

- The first of the proposed military inspections is accomplished by the Ministry of National Defence exclusively for the needs of the government. The previous practice clearly illustrates that the Strategic Defence Inspection carried out between 2004 and 2006 has only partially fulfilled its presumed functions, which was the ultimate outcome of all the political factors taking place in the national defence department and on the Polish political scene in general. The effectiveness of the second edition of the Strategic Defence Inspection carried out in 2010 cannot yet be realistically assessed due to the relatively short period of time that passed between now and the date of the inspection.

- The second of the national defence inspections is carried out under the auspices of the Republic of Poland's President through National Security Bureau. At the moment it has no connection with politics, the national defence strategy or Strategic Defence Inspection. Taking into special account the previous practice in Poland, one may form an opinion that compared to that all the suggested solutions shall be merely a resultant of political configurations in the current parliamentary and governmental system. 
This fact illustrates with ease the essence of deficiencies that exist in Poland in the top-down manner of described scope and otherwise confirms exactly the aforementioned theses of S. Koziej and W. Kitler. Thus, since the required condition for national security system effectiveness is its effective organisation and proper equipment that may guarantee adequately fast and efficient operation in times of peace, crisis or war and as a reaction to any type of present threat or emergency, it should be underlined that the particular instrument that may guarantee such effectiveness is the manoeuvres with the participation of all the governmental bodies. The instruments that remain international in their character and, at the same time, a certain additional element that helps to verify the system's effectiveness are the planned and cyclical manoeuvres of NATO - CMX and the European Union - CRISEX (Gryz 2013, p. 107).

The need for a better adaptation of the strategic security management to the most important needs of a state's development formed the very foundations of the changes concept concerning the areas of forming, providing and the effective accomplishment of Polish security priorities undertaken by the government towards the end of 2009. Guided by pragmatism, in 2008, the government commenced its vast work on the further update of the Country Development Strategy for the years 2007-2015. Originally, this strategy was supposed to indicate the exact directions of activities undertaken and successfully accomplished by the state in each area of activity in relation to the previously identified, priority interests ultimately resulting from the society's need to develop. Work on a further update of the Country Development Strategy was undertaken by the Ministry of Regional Development. Among others, this solution is supposed to allow for the following (Gryz 2013, p. 108):

- Legislative changes, that is the amendment of the December 6, 2006 Act on the rules of development policy implementation and the Public Finance Act.

- Carrying out a real assessment of the strategy and the numerous development programmes with the medium-term country development strategy.

- Accepting the proposition of different system solutions in the form of the Poland development system management premises.

- Organising the official strategic documents by accepting the plan of development strategy. 
- Preparing the fundamental strategies of development, including but not limited to the Long-term Strategy of Country Development, Strategy of Country Development as well as the nine target development strategies. As a result, is was supposed to result in e.g. the proper reduction of the legally binding strategic documents in Poland.

- Strengthening the public administration sector through a series of training courses concerning the management of development

As a result of these changes, the following operations should also take place: the division of the current strategies and policies into the respective theme units always related with the target development strategies; drawing 9 complex development strategies including the most important challenges typically connected with development; organisation of the former strategies and policies; thematic subordination of the development programmes to the strategies of development; acknowledging the official documentation excluded from the general strategic documents system in their entirety as not legally biding. Against this background, the Republic of Poland's National Security Strategy is supposed to be one of the nine development strategies.

Due to the work commenced for this document, one may form a prediction that it will entail introducing order to Poland's security and defence domain in direct relation to the main priorities of the country's development.

The utility of strategic approach for the proper national security formation may by all means be specified as the precondition for a highly effective activity on the one hand, and on the other, one of the most important challenges of political security. The contemporary understanding of the strategy situates it in a fairly tight relationship with security policy. As it may be further assumed, both politics and the entire strategy can be properly distinguished by the so-called specified goals angle, that is the socially important values and the top-down assumed, especially in the case of the drawn strategy, long-term perspective (Kuźniar 2005, p. 180).

Identification of strategy and policy in relation to the fairly broadly understood security of an individual, community, nation or state allows for freely attributing the strategic approach to the fairly important function of ruling that is to provide the conditions of existence and development for the people. As was already stated 
in the introduction, the strategic approach in the close future relating directly to military issues of waging a war, is only presently applied in many a field, sometimes fairly unrelated to military conflict nor even to the activity of governmental bodies responsible for the state's security (Jakubczak and Flis 2006, p. 122).

The very expression "strategy" comes from Greek and it originally meant none other than the art of commanding an army. Later, the word also started to denote a certain ability to rule over a country. Traditionally, the strategy was attributed to the grave problems of preparing and waging a war. However, due to the constant increase of societies' life complexity and the significant complicating of the very phenomenon of war, it became necessary to include non-military aspects into the complex strategy. The strategy, however, ceased to be merely a means to achieve the intended security goals and became simply a synonym for a highly effective action concerning state policy. A strategy became an art of achieving the intended goals (Gryz 2013, p. 94).

The development of the entire strategy seen from a wider historical perspective, which is from ancient times, is easy to interpret from two parallel, complex processes. The first of them is specified by the considerable increase in the complexity of using force in the state's external relationship used to constantly expand the whole political and institutional, social or economic context of this phenomenon. On the other hand, due to the external challenges, the state functions related to its security started to develop and ceased only to denominate the matters of using a military force. As was observed starting from the half of the $19^{\text {th }}$ century, the process of gradual civilisation of strategy has commenced.

The strategy as an instrument of security of sorts remains thus in the proper relationship with the significant changes in perception of the security itself, including the broadening of the previous interpretation of the term considering the subject as well as the object approach. Presently, in the security theory, the dominating notion is that of a strategy as a choice made on the basis of knowledge and detailed strategic analysis, the proper and even necessary means that remain at a state's disposal to achieve goals and effectively accomplish the tasks specified in detail by security policy (Gryz 2013, p. 99).

In the presented approach, the relationship between the security policy itself and the strategy is an expression of the general relationship in which the former 
rules over the latter. It is the policy that clearly specifies the goals and the strategy is a means to achieve them. In other words, policy determines the direction of strategy. Following this approach, one may finally speak about the functional subordination of a strategy to a state's policy. In other words, by the specific national security strategy, one may by all means understand a choice made on the basis of knowledge and detailed strategic analysis of proper and necessary means that remain at a state's full disposal to achieve final goals and comprehensively accomplish the tasks specified by security policy (Baylis, Writz, Gray and Cohen 2009, p. 73).

The strategy rationalises any political activity supporting its objectification. Thus, the applied security policy means a complex process of constant definition of the functional goals providing the state security in fullness and in accordance with the top-down accepted presumptions. In this situation, the specifically drawn path to such goals is the security strategy that is none other than the exact drawing of more or less specified operational programmes in various domains aimed at state security. Thus, both the security policy and the whole strategy can be named an instrument of security. The foundation of the current policy is clearly formed by the process of goals identification mainly in the security domain and the strategy is a form of a directive (way) towards their successful accomplishment. Both domains of the executive power activity are therefore strictly political; thus, it becomes justified to present them as the instruments of a state's political security. The important relationship underlined here provides foundations for a strategic way of thinking in politics. One may attribute to it the following features:

- The holistic character in the spatial as well as functional sense

- Long-term nature (a period of at least a couple of years)

- Foundation of the detailed analysis of the international environment with the direct consideration of various favourable and unfavourable factors

- The structure of goals that is organised only in terms of their hierarchy

- Dependency of the selection of means of accomplishment with the possessed resources, complex goals and the very method of their use

- Identification and successful accomplishment through the possibly homogenous and integrated state bodies.

Such an approach may be, in the completely functional sense, distinguished as a complex of the accepted criteria introducing order into the approach to security 
policy as such in the circumstances of an ever-growing syndrome of instability and unpredictability in the vicinity of the security subject itself. Such a syndrome is discerned in many very different contexts: the globalisation determinants, the IT revolution and their various social consequences or interdependencies, etc. Looking at the whole issue from the typically strategic angle entails the creation of a properly organised theoretical vision, which, by the very fact of creation, can have a crucial and notable practical value as a means of state policy and namely its instrument. However, it takes place only when all the strategic goals are socially identified as very important and can count on approval in the long run. The changeability so characteristic for the complex political processes (appointing the governmental bodies and holding power) evokes more and more often the conviction that for the sake of state security, it is appropriate to accept the rule according to which policy will be subordinate to strategy (Gryz 2013, p. 96).

\section{Conclusion}

Currently, worldwide, the numerous non-military very important aspects of security are becoming more and more important. This evolution is always accompanied by a change in the attitude towards the fight carried out against the constantly appearing serious threats that were never known before. It is mainly the innovation, flexibility and the professionalism of the undertaken activities that will be decisive for this fight's effectiveness. The new challenges are met mainly by the special, unique and new work methods, specialist personnel and access to state-of-the-art technical achievements. These are the most important factors causing them to take the most prominent place among the institutions responsible for a state's national security protection.

To date, Poland has been free from immediate threats. It does not, however, mean that we have a full guarantee of security in the future. At each and every moment, our country should be prepared for a terrorist attack. For terrorism forms one of the most visible and spectacular contemporary threats to security. It introduces fear and violence to politics, putting the regimes' stability on the line and society's psychological stability. The cooperation between terrorist organisations and the interested countries or criminal organisations not only facilitates for them the 
accomplishment of their own goals, but also provides completely new means of their accomplishment.

A system transformation has taken place in Poland as well as the numerous changes in the international relationships on the European continent. Only at the turn of the 1980s and 1990s did these factors create a completely new situation mainly in the scope of ensuring state security. The security of the Polish state, its internal and external circumstances, were influenced mainly by the changes occurring in this state's closer or further proximity on the European continent. They were exemplified by the fall of the eastern block, creation of new states on the territory of the disintegrating Union of Soviet Socialist Republics, the increasing integration between the Western European countries within the European Commonwealth and the will for cooperating with former political and military enemies on the side of NATO member countries.

In the contemporary circumstances, the priorities are national security, creating an efficient country, effective administration and the ability to face new challenges. Poland should create its security in a different manner than in previous years. Security and public order are too precious values in general. The whole administrative complex should be responsible for maintaining them, and the individual units of such complex should compete with one another. Only such a system can guarantee such a mode of task accomplishment that will really produce the desired results.

To sum up, the condition of highly effective state functioning is none other than the universality of various bodies' activities and of various public administration institutions. To fulfil this crucial condition, one should actively strive to create a suitably integrated system of strategic planning understood as any activities that will be assigned to a certain accomplishment of goals directly resulting from national security strategy. The forms of successful accomplishment may be, in practice, expressed in the form of plans and various programmes, which in relation to the strategy will constitute its fundamental interpretation. It should be emphasised that the universality of various bodies and public administration institutions' activities should directly relate to fulfilling very important conditions of completeness, suitability, exclusiveness, feasibility and acceptability. 


\section{References}

Baylis, J., Writz, J., Gray, C. S., Cohen, E. (eds), 2009. Strategia we wspótczesnym świecie. Wprowadzenie do studiów strategicznych. Wydawnictwo Uniwersytetu Jagiellońskiego, Cracow.

Boudon, R., 2009. Logika działania społecznego. Wstęp do analizy socjologicznej. Nomos, Cracow.

Christensen, J. G., Petersen N., 2005. Managing Foreign Affairs. A Comparative Perspective. Danish Institute for International Studies, Copenhagen.

Cline, R. S., 1975. World Power Assessment. A Calculus of Strategic Drift. Westview Press, Boulder.

Griffin, R. W., 2004. Podstawy zarzadzania organizacjami. Wydawnictwo Naukowe PWN, Warsaw.

Gryz, J. (ed.), 2008. Bezpieczeństwo w stosunkach transatlantyckich. Adam Marszałek, Toruń. Gryz, J., 2013. Strategia bezpieczeństwa narodowego Polski. Wydawnictwo Naukowe PWN, Warsaw.

Jakubczak, R., Flis, J., 2006. Bezpieczeństwo narodowe Polski w XXI wieku. Bellona, Warsaw.

Kapłan, R. D., 2008. Polityka wojowników. Dlaczego przywództwo potrzebuje pogańskich wartości. Sprawy polityczne, Elbląg.

Karkoszka, A., 2009. Gra cywilno wojskowa. Polska Zbrojna, 36.

Koziej, S., 2001. Bezpieczeństwo, istota, podstawowe kategorie i historyczna ewolucja. Wydawnictwo Biura Bezpieczeństwa Narodowego, Warsaw.

Koziej, S., 2012. Strategiczny Przeglad Bezpieczeństwa Narodowego. Wydawnictwo Biura Bezpieczeństwa Narodowego, Warsaw.

Kugler, R.L., 2006. Policy Analysis in National Security Affairs. New Methods for New Era. National Defence University Press, Washington.

Kuźniar, R., 2005. Polityka i siła. Studia strategiczne - zarys problematyki. Scholar, Warsaw.

Leszczyński, M., Gumieniak, A., Owczarek, L., Ochocki, R., 2013. Bezpieczeństwo w wymiarze lokalnym. Wybrane obszary. Difin, Warsaw.

Lisiecki, M., 2011. Zarządzanie bezpieczeństwem publicznym. WAiR, Warszawa.

Misiuk, A., 2013. Instytucjonalny system bezpieczeństwa wewnętrznego. Difin, Warsaw.

Nęcka, E., Orzechowski, J., Szymura, B., 2009. Psychologia poznawcza. Wydawnictwo Naukowe PWN, Warsaw.

Olszewski, E., 2004. Doktryny i ruchy wspótczesnego ekstremizmu politycznego. Wydawnictwo UMCS, Lublin.

Samuelson, A., Nordhaus, W., 2004. Ekonomia. Wydawnictwo Naukowe PWN, Warsaw. Urbaniak, J., 2009. Wyzwania Strategicznego Przegladu Obronnego. Bellona, Warsaw.

Wojtaszczyk, K. A., Jakubowski, W. (eds.), 2002. Społeczeństwo i polityka. Podstawy nauk politycznych. Aspra-Jr, Warsaw. 